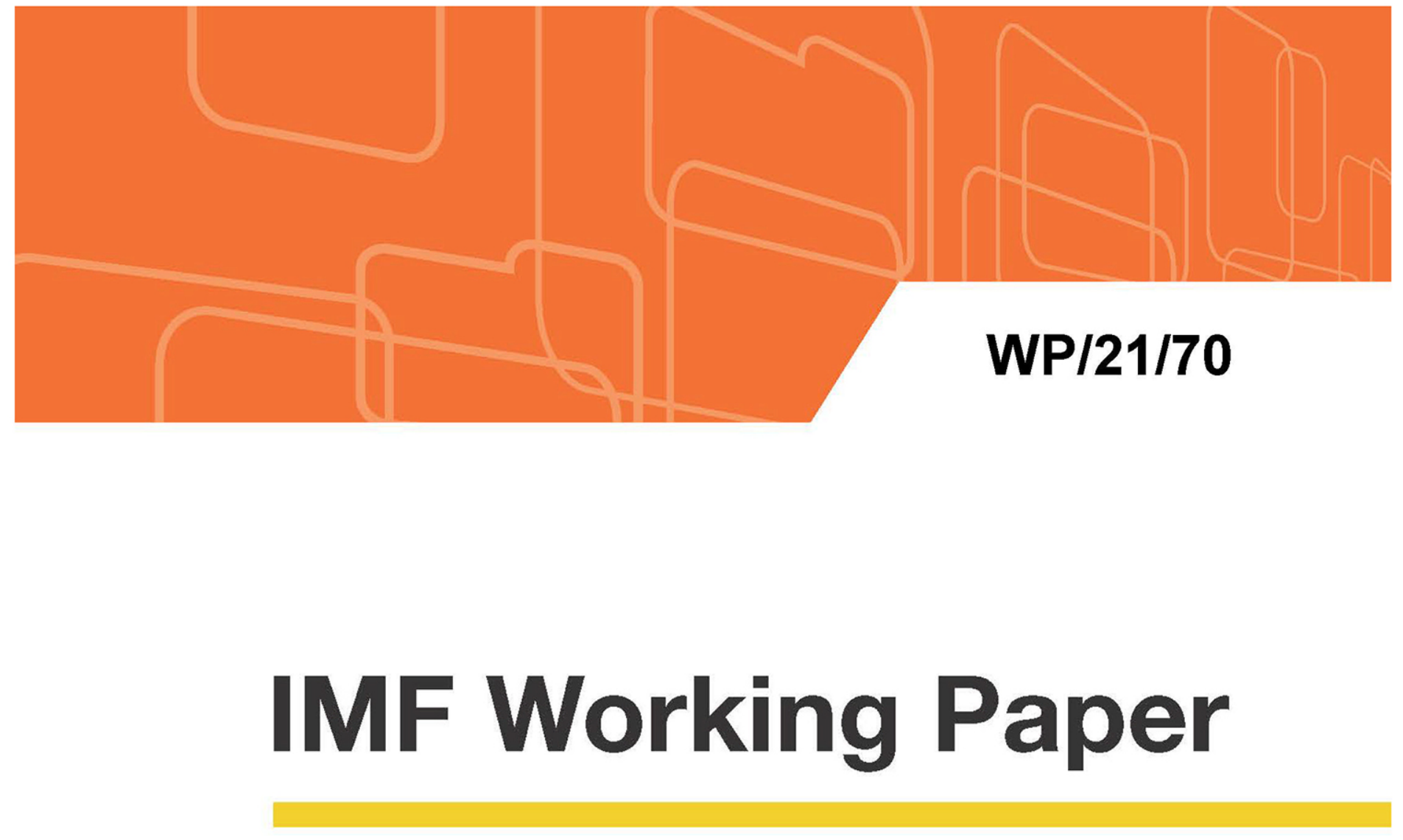

\title{
Supply and Demand Effects of Unemployment Insurance Benefit Extensions: Evidence from U.S. Counties
}

by Klaus-Peter Hellwig

IMF Working Papers describe research in progress by the author(s) and are published to elicit comments and to encourage debate. The views expressed in IMF Working Papers are those of the author(s) and do not necessarily represent the views of the IMF, its Executive Board, or IMF management. 


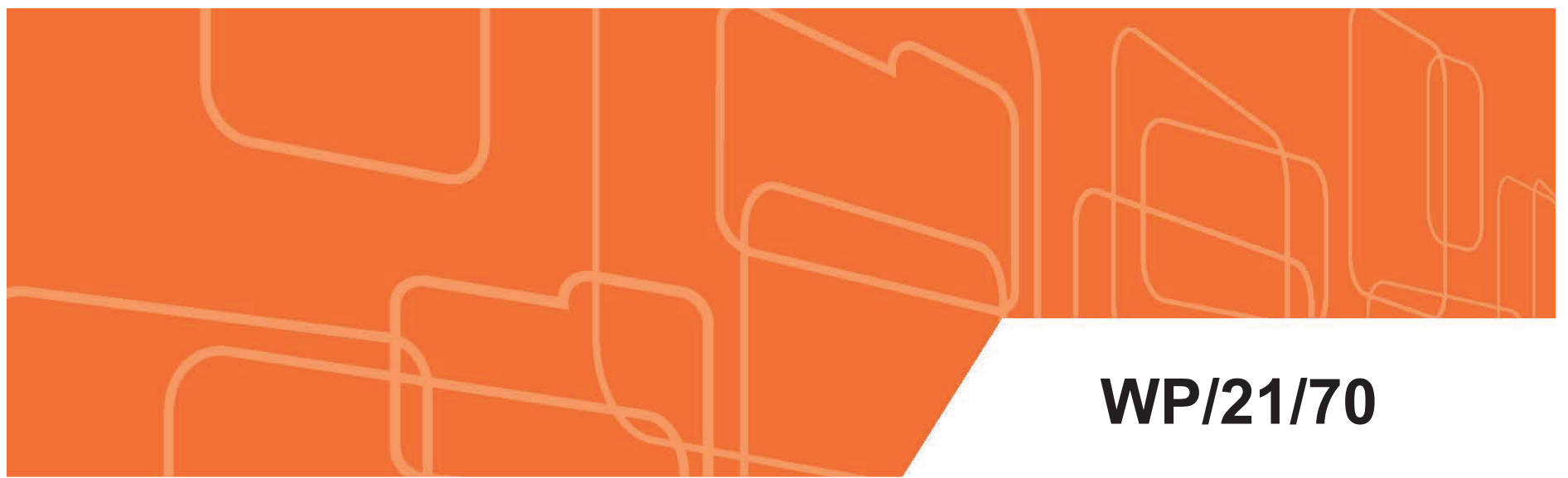

IMF Working Paper

\section{Supply and Demand Effects of Unemployment Insurance Benefit Extensions: Evidence from U.S. Counties}

by Klaus-Peter Hellwig

IMF Working Papers describe research in progress by the author(s) and are published to elicit comments and to encourage debate. The views expressed in IMF Working Papers are those of the author(s) and do not necessarily represent the views of the IMF, its Executive Board, or IMF management.

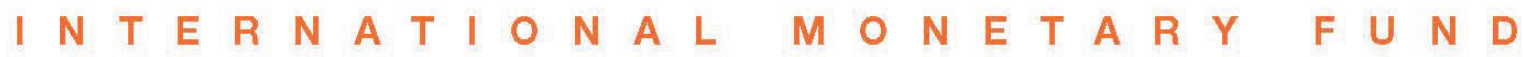




\title{
IMF Working Paper
}

Asia Pacific Department

\section{Supply and Demand Effects of Unemployment Insurance Benefit Extensions: Evidence from U.S. Counties}

\section{Prepared by Klaus-Peter Hellwig}

Authorized for distribution by Rahul Anand

March 2021

\section{IMF Working Papers describe research in progress by the author(s) and are published to} elicit comments and to encourage debate. The views expressed in IMF Working Papers are those of the author(s) and do not necessarily represent the views of the IMF, its Executive Board, or IMF management.

\begin{abstract}
I use three decades of county-level data to estimate the effects of federal unemployment benefit extensions on economic activity. To overcome the reverse causality coming from the fact that benefit extensions are a function of state unemployment rates, I only use the within-state variation in outcomes to identify treatment effects. Identification rests on a differences-indifferences approach which exploits heterogeneity in county exposure to policy changes. To distinguish demand and supply-side channels, I estimate the model separately for tradable and non-tradable sectors. Finally I use benefit extensions as an instrument to estimate local fiscal multipliers of unemployment benefit transfers. I find (i) that the overall impact of benefit extensions on activity is positive, pointing to strong demand effects; (ii) that, even in tradable sectors, there are no negative supply-side effects from work disincentives; and (iii) a fiscal multiplier estimate of 1.92 , similar to estimates in the literature for other types of spending.
\end{abstract}

JEL Classification Numbers: E62; J65; J68

Keywords: Automatic stabilizers; Fiscal multiplier; Labor markets

Author's E-Mail Address: khellwig@,imf.org 


\title{
Supply and Demand Effects of Unemployment Insurance Benefit Extensions: Evidence from U.S. Counties
}

\author{
Klaus-Peter Hellwig*
}

February 16, 2021

\begin{abstract}
I use three decades of county-level data to estimate the effects of federal unemployment benefit extensions on economic activity. To overcome the reverse causality coming from the fact that benefit extensions are a function of state unemployment rates, I only use the within-state variation in outcomes to identify treatment effects. Identification rests on a differences-in-differences approach which exploits heterogeneity in county exposure to policy changes. To distinguish demand and supply-side channels, I estimate the model separately for tradable and non-tradable sectors. Finally I use benefit extensions as an instrument to estimate local fiscal multipliers of unemployment benefit transfers. I find (i) that the overall impact of benefit extensions on activity is positive, pointing to strong demand effects; (ii) that, even in tradable sectors, there are no negative supply-side effects from work disincentives; and (iii) a fiscal multiplier estimate of 1.92, similar to estimates in the literature for other types of spending.
\end{abstract}

JEL classification: E62; J65; J68.

Keywords: Automatic stabilizers; Fiscal multiplier; Labor markets.

\footnotetext{
*International Monetary Fund; email: khellwig@imf.org.

${ }^{\dagger}$ I thank Philip Barrett, Samir Jahan, Paolo Mauro, Steven Pennings, Carlo Pizzinelli, Farzad Saidi, Ippei Shibata, Philippe Wingender, and seminar participants at the IMF for many insightful comments and discussions. All errors are my own.

${ }^{\ddagger}$ The views expressed in this paper are those of the author and do not necessarily represent the views of the IMF, its Executive Board, or IMF management.
} 


\section{Introduction}

The question whether more generous unemployment insurance (UI) benefits are an effective way to stabilize the business cycle continues to divide policy makers. In the United States, the unprecedented increase in unemployment caused by the COVID-19 shock in 2020 has put this question back at the center of the economic policy debate, with vivid reminders of the sharp differences in views: ${ }^{1}$

"This bill creates an incentive for people to be unemployed for the next 4 months" - Senator Rick Scott

"Is that going to mean that someone now becomes lazy and won't go back to work? I don't think so. I think a lot of people will use that money and need that money and ... will put it right back in the economy. ... By and large, these are hard-working people who, with an additional $\$ 1,000$, may finally be able to buy that refrigerator, may finally be able to get that car fixed, and may finally be able to get some dental work done." - Senator Dick Durbin

The academic literature, too, is split on the extent to which UI benefits create supply-side distortions by affecting job search incentives and labor market outcomes. ${ }^{2}$ And not enough is known about whether, as claimed by Senator Durbin, recipients indeed put their benefit money right back in the economy and thereby boost aggregate demand.

To shed light on these questions, I use county-level data spanning more than three decades and estimate the local economic impact of UI benefit duration extensions granted under four federal government programs: the permanent Extended Benefits program, the 1991-94 Emergency Unemployment Compensation program, the 2002-04 Temporary Extended Unemployment Compensations program, and the 2008-13 Emergency Unemployment Program. These programs have provided additional benefit weeks for workers who had reached the end of their regular state UI benefit duration without finding a job.

Identifying the causal effects of additional benefit weeks on local outcomes requires overcoming the issue of reverse causality: because extension programs were instated during times of high unemployment and because their generosity varied across states as a function of the state unemployment rate, economic activity is negatively correlated with UI benefit generosity. Therefore, rather than asking whether benefit extensions affect a state's aggregate economic dynamics, I ask whether they can explain the within-state variation in economic

\footnotetext{
${ }^{1}$ Quotes are from the March 25, 2020, Senate floor debate over additional UI benefits under the CARES Act to address the economic fallout from the Covid-19 pandemic.

${ }^{2}$ see Chodorow-Reich and Coglianese (2019) for a detailed survey
} 
dynamics at the county level. I exploit the fact that there is considerable cross-sectional variation in the extent to which counties within the same state benefit from UI policy changes at the state level.

To give an example, each panel of Figure 1 shows the per capita UI benefit transfers and per capita unemployment rates for counties in the state of Iowa before and after the introduction of benefit extensions. As one would expect, per capita transfers are increasing in the county unemployment rate (naturally, counties without unemployment would not receive any benefits), and the slope depends on the benefit generosity. Hence, the effect of a benefit extension is to increase the slope of the relationship between unemployment rates and aggregate UI benefit transfers. This change in slope means that high-unemployment counties benefit more from a state-wide benefit extension than low-unemployment counties, which allows me to pursue a differences-in-differences (DiD) approach, comparing the impact of additional benefit weeks on high versus low unemployment counties.

The DiD approach is implemented by constructing a treatment variable along the lines of Bartik (1991): an interaction term between state-level policy changes (i.e., benefit extensions) and county-level lagged historical average UI benefit receipts (as a share of income). Counties that typically receive more benefits are more exposed to policy changes than counties are more exposed to the treatment. ${ }^{3}$ Note that treatment intensity here is a continuous variable. While this may look different from classical examples of the DiD approach where observations are divided into discrete treatment and control groups (such as Card and Kruger, 1994), the logic of DiD estimators extends naturally to cases with continuous treatment intensity (see Chodorow-Reich, 2020).

The use of long lags implies that local variation in treatment intensity comes from structural rather than cyclical factors: structural characteristics such as workforce or industry composition lead to cross-county differences in unemployment rates that are highly persistent over time. ${ }^{4}$ To ensure that the drivers behind the changes in benefit extensions are controlled for, I include a full set of state-by-year fixed effects.

My analysis proceeds in several steps. Using the DiD specification, I first estimate the reduced-form relationship between benefit extensions and economic outcomes such as employment growth and labor earnings growth at the aggregate level. To separate the demand

\footnotetext{
${ }^{3}$ The approach is somewhat similar to Pennings (2020) but applied at the county level and using longer lags to capture differences in county exposure to the treatment (as in Nakamura and Steinsson, 2014). Pennings estimates the effect of one-off stimulus transfers to households on state-level GDP. Nakamura and Steinsson use a similar approach to estimate the defense spending multiplier.

${ }^{4}$ Note that, in addition to the current unemployment status, benefit eligibility and weekly benefit amounts also depend on a worker's employment history and wage level.
} 
Figure 1: Iowa: County-level per-capita benefit transfers and unemployment rates

(a) $1991-92$

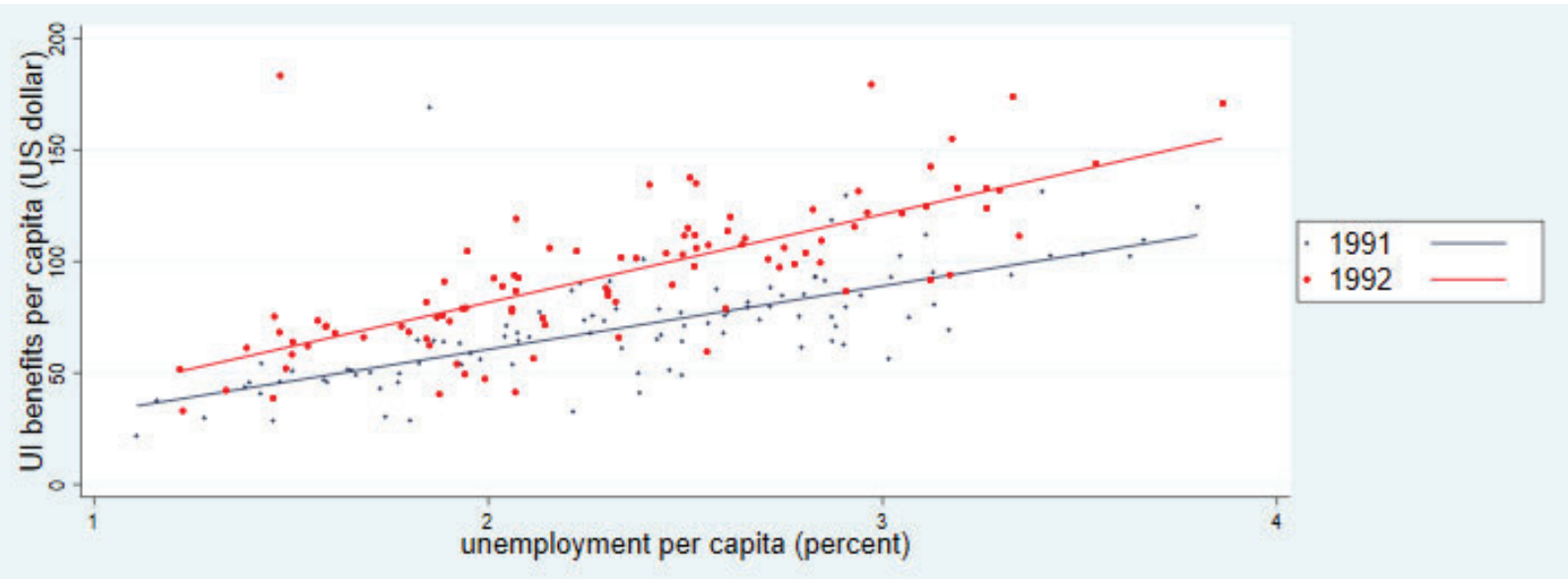

(b) 2001-02

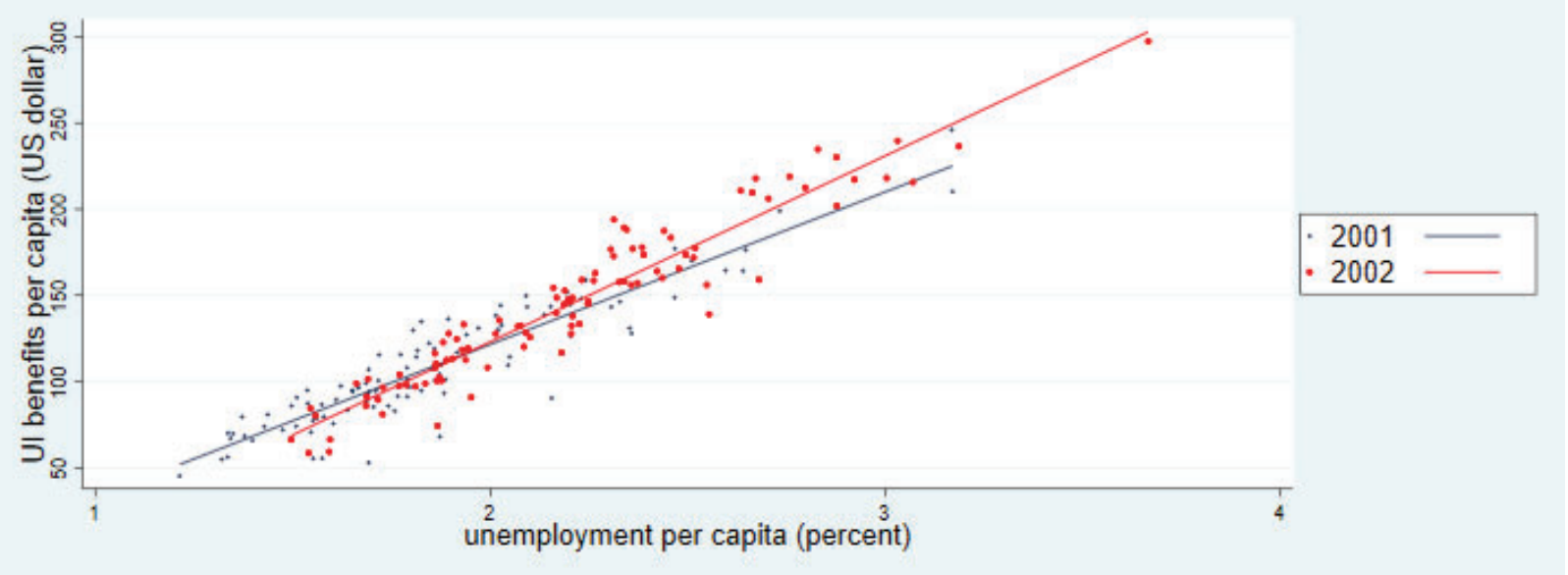

(c) $2007-08$

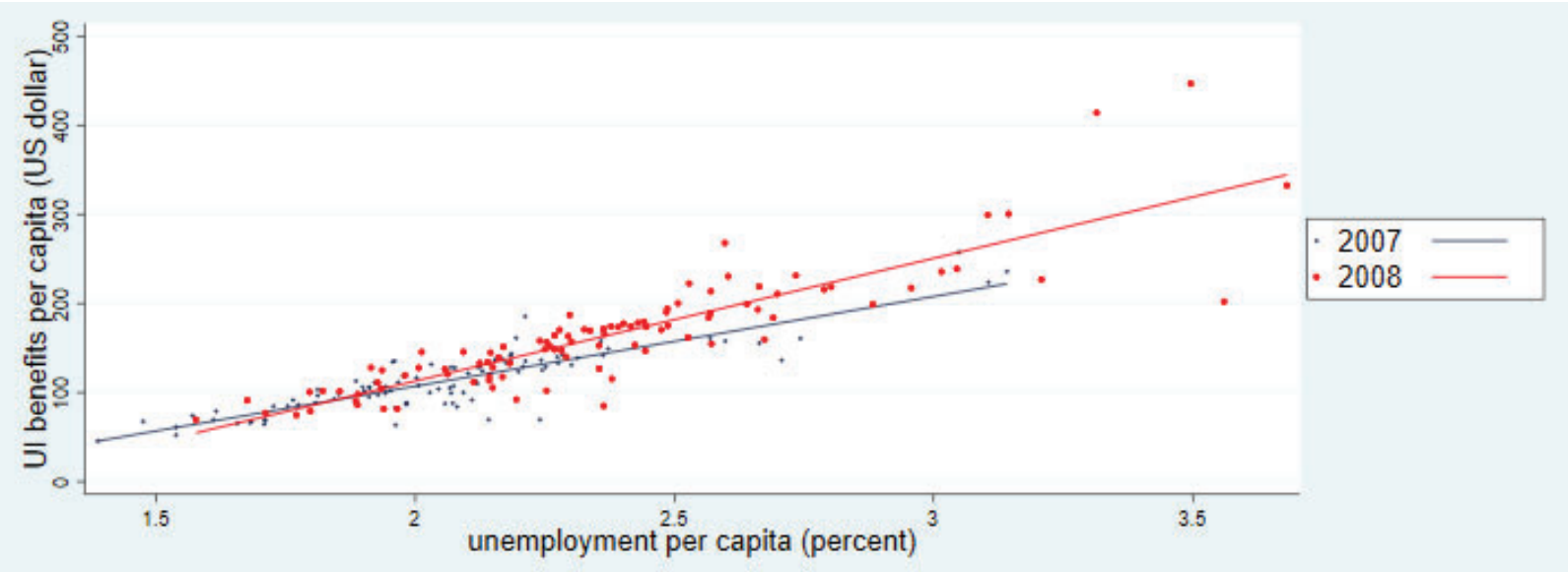

Sources: Bureau of Labor Statistics, Bureau of Economic Analysis, author's calculations. 
and supply side effects, I then follow Mian and Sufi (2014) and re-estimate the model separately for various disaggregated sectors of the economy. In theory, the supply effects (reduced labor supply due to more generous UI benefits) would hit firms in tradable sectors by putting them at a disadvantage relative to their out-of-state or international competitors who don't face the same cost shock. By contrast, firms in non-tradable sectors would find it easier to pass this cost on to consumers, given that all of their competitors are local and therefore face the same cost shock. On the demand side, non-tradable sectors are more sensitive to a local stimulus than tradable sectors, since the latter mostly cater to out-of-state customers whose demand remains unchanged.

As a final step, to relate the effects of UI benefit extensions to their cost, I use the DiD specification to estimate fiscal multipliers from benefit transfers, using the Bartik-type treatment variables (i.e., de-jure benefit generosity) as instruments for benefit transfer payments (i.e., de-facto benefit generosity).

The estimated effects of UI benefit extensions on employment, labor force participation, and labor earnings are positive and statistically significant: the boost to aggregate demand from additional benefit weeks is more than enough to offset any labor market disincentives. Consistent with this interpretation, I find that the positive effect is driven by non-tradable sectors such as retail trade and construction. For tradable sectors, I do not find a significant treatment effect. Hence, there is no robust evidence that more generous benefits generate labor market disincentives: if these disincentives mattered, then we should see a significantly negative effect on employment in tradable sectors. Similarly, I do not find any effect of benefit extensions on average wages. My results most likely understate the size of demand effects, as they fail to capture any increase in demand for tradable goods: Since a large share of tradable goods are ordered across county lines, the boost in local demand affects firms in other counties, states, or countries in a similar way and is therefore differenced out by statetime fixed effects. ${ }^{5}$ Even when ignoring such spillovers, the magnitude of my estimates is economically significant. They imply, for example, that total nationwide employment in 2014 would have been higher by half a million million jobs if the Emergency Unemployment Compensation program had not expired on January 1st of that year. ${ }^{6}$

\footnotetext{
${ }^{5}$ Dupor et al (2019) find that, due to trade linkages, the aggregate consumption multiplier is almost twice the local estimate.

${ }^{6}$ Of course, by nature of the difference-in-difference approach such estimates capture only partialequilibrium effects that cou Of ld be dampened by additional general equilibrium effects not captured by my partial equilibrium setup (see, Nakamura and Steinsson, 2014). However, while such forces are a theoretical possibility, Chodorow-Reich (2020) shows that, for government spending policies, partial equilibrium estimates derived from subnational data tend to underestimate the aggregate effect, as spillovers are not fully accounted for.
} 
The size of the estimated effect of benefit extensions is perhaps surprising, given that - as pointed out by Chodorow-Reich and Coglianese (2019) - only a fraction of the unemployed exhaust their regular benefits. Indeed, I find that an extension of maximum benefit duration by three months increases the average county's aggregate benefit receipts by less than 0.02 percent of annual household income. But per additional dollar in UI benefits coming from federal benefit extension programs, a county's private sector labor earnings increase by 1.925 dollars.

This fiscal multiplier estimate is fairly similar to estimates previously found in the literature on local fiscal multipliers from other types of government spending (e.g., Nakamura and Steinsson, 2014; Suarez-Serrato and Wingender, 2014; Shoag, 2016; Pennings, 2020) and general equilibrium government transfer multipliers (e.g., Oh and Reis, 2012; Giambattista and Pennings, 2017; Bayer et al., 2020; Faria-e-Castro, 2020). It is therefore larger than what one might expect in light of potential job-search disincentive effects. Three factors could explain the large multiplier estimate: (i) unemployed workers have a high marginal propensity to consume (see), leading to a larger Keynesian demand effect; (ii) a more generous safety net reduces the need for precautionary savings of employed workers (as in McKay and Reis, 2016); and (iii) UI benefits play a strong role in stabilizing housing prices (as shown in Hsu et al., 2018), leading to a wealth effect that affects all homeowners. Consistent with this third channel, I find that the effect of benefit extensions on employment growth is particularly strong in the construction sector.

In addition to the literature on local fiscal multipliers, the paper also contributes directly to a growing literature on the labor market implications of UI benefit generosity. While some recent microeconomic studies find no effect of benefit generosity on unemployed workers' willingness to accept a job (Krueger and Mueller, 2016; Jaeger et al., 2020), others provide evidence that extending the UI benefit duration leads to reduced job search effort (Card, Chetty, and Weber, 2007; Card and Levine, 2000; Krueger and Mueller, 2010; Lalive and Zweimueller, 2004; Lalive et al, 2006; Marinescu, 2017), though the effect declines in recessions (Schmieder et al., 2012; Kroft and Notowidigdo, 2016). At the macro level, the literature has focused on whether changes in individual search behavior in response to more generous UI policies translate into higher unemployment rates. ${ }^{7}$ In theory, the disincentive effects of UI policy changes could be either amplified or dampened because firms respond by posting fewer job openings or because the intensity of a worker's job-search can depend on

\footnotetext{
${ }^{7}$ It should be noted that higher unemployment is not always an undesirable outcome. Chetty (2008) finds that, while increasing unemployment duration, more generous UI benefits improve the allocative efficiency of the labor market as workers are less likely to accept an unsuitable job because of household liquidity constraints.
} 
other worker's search behavior (see, Lalive et al., 2015). Hagedorn et al. (2013, 2015) find that the resulting effects on raising unemployment are large, whereas Chodorow-Reich and Karabounis (2019), Lalive et al. (2015), Landais et al. (2018a, 2018b) find that they are relatively small. Marinescu (2017) finds no robust effect on the number of new job openings. Much of the labor literature is silent on whether the supply-side effects of UI benefits could be offset by Keynesian demand effects, but McKey and Reis (2016) and Kekre (2016), using general equilibrium models, find that this is indeed possible. To my knowledge, my present paper is the first to empirically estimate the relative magnitude of supply and demand effects of benefit extensions, showing that Kekre's (2016) equilibrium results hold in the data. My paper is perhaps most closely related to Di Maggio and Kermani (2016) who find that more generous benefits can soften the impact of an exogenous demand shock. Using a different empirical strategy, they find a fiscal multiplier of the same size as mine. ${ }^{8}$

The paper is organized as follows. Section 2 describes the benefit extension programs in more detail. Section 3 discusses the empirical approach and data. Section 4 presents the reduced form estimates for the effect of benefit extensions on economic outcomes, both at the aggregate level and disaggregated by sector. Section 5 presents the instrumental variables approach to estimate fiscal multipliers. And Section 6 concludes.

\section{Background: federal benefit extensions for state UI programs}

The state UI system, a joint federal-state program established in 1935, is by far the largest among the public UI schemes in the US. ${ }^{9}$ Other schemes include UI for federal government employees, UI for former military personnel, and the Railroad UI, all of which are comparatively small. State UI schemes are financed through state and federal payroll taxes, and state UI funds are backstopped by the federal government. That is, in times of larger resource needs, state UI funds can borrow from the federal government. Since each state designs and administrates its own state UI system, following guidelines established by federal law, there is considerable variation in the eligibility requirements and generosity of unemployment compensation across states. The formulae to compute an eligible unemployed worker's weekly

\footnotetext{
${ }^{8}$ Di Maggio and Kermani (2016) use a time-invariant measure of benefit generosity and exploit heterogeneity in county exposure to demand shocks, whereas I study changes in benefit extensions over time, exploiting heterogeneity in county exposure to policy changes.

${ }^{9}$ Detailed chronologies of UI legislation can be found under N.Y. State Department of Labor (2014) and U.S. Department of Labor (2018).
} 
benefit amount vary with respect to the role of factors such as the worker's previous duration of employment, salary, or the number of dependents. Regardless of the exact formula, all states specify a cap on weekly benefit amounts.

Changes in the parameters set by the states are relatively infrequent. However, due to federal government policies, eligibility rules have varied considerably with the business cycle: The extended benefits (EB) program, created in 1970, provides for an additional 13 weeks of benefits in states with high unemployment, financed equally from state and federal funds. ${ }^{10}$ Moreover, in each nation-wide recession since 1958, Congress passed discretionary measures to temporarily extend the maximum benefit duration (see Lake, 2002). For the period studied in this paper, these are the Emergency Unemployment Compensation program of 1991-1994, the Temporary Extended Unemployment Compensation program of 2002-2004, and the Emergency Unemployment Compensation program of 2008-13:

- The Emergency Unemployment Compensation (EUC) Act of 1991 became effective in November of that year. It de facto temporarily replaced the EB program (Lake, 2002). It extended the benefit duration for all states by at least 13 weeks, with higher extensions for high-unemployment states. ${ }^{11}$ A "reachback" provision allowed unemployed workers who had exhausted their regular state UI benefits after March 1991 to claim benefits under the EUC program. Until its expiration in April of 1994, the program was amended several times to modify the parameters, including to gradually reduce the maximum number of benefit weeks, while maintaining the two-tiered structure.

- The Temporary Extended Unemployment Compensation (TEUC) program was signed into law on March 9, 2002 and expired in March of 2004. It provided up to either 13 or 26 weeks of extended benefits to workers who have exhausted their regular benefits, depending on the state unemployment rate (Lake, 2003). According to the implementing guidelines (U.S. Department of Labor, 2002), the TEUC program left entitlements under the EB program unaffected, though state governors had discretion over whether to pay TEUC before EB benefits.

- The Great Recession led to the creation of the Emergency Unemployment Compensation program of 2008, passed in June of that year. Initially granting extensions of up to 13-weeks, the program was modified several times: In November of 2008, extensions were increased up to 20 weeks for all states, and additional support - a second tier -

\footnotetext{
${ }^{10}$ States can opt to increase the added benefit weeks under the EB program to 20 weeks instead of 13 in times of higher state unemployment.

${ }^{11}$ States were considered to have high unemployment if either the total unemployment rate or the insured unemployment rate were above a specific threshold (see Annex A).
} 
Figure 2: Annual aggregate UI benefit payments, 1990-2018

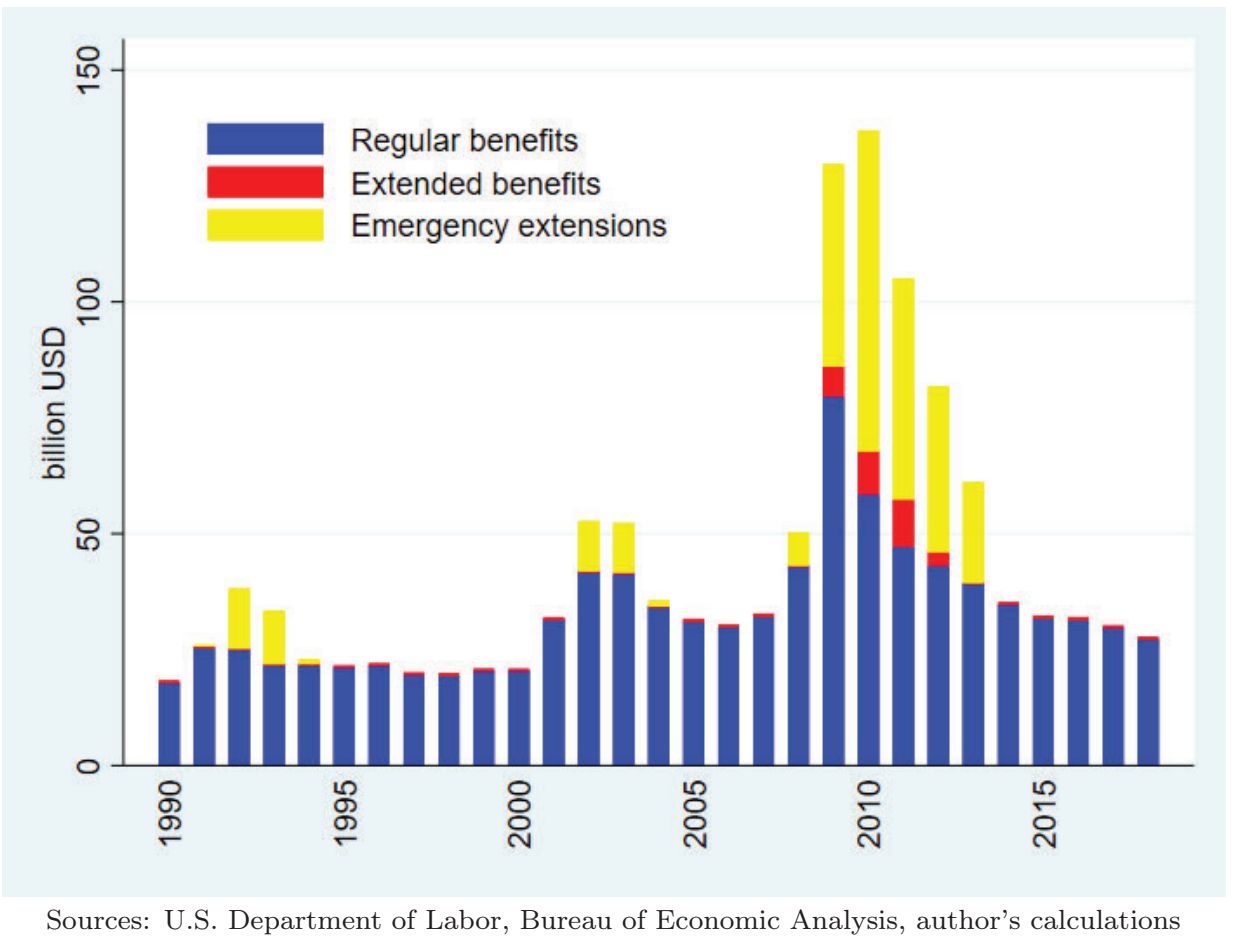

was added, providing further extensions by 13 weeks in high unemployment states. In November of 2009, the second tier was expanded to all states, and a third and fourth tier were created. The generosity of the four different tiers changed over time, due to modifications in the law. At its peak in mid-2012, the program allowed for EUC extensions of up to 63 weeks states with all tiers activated. The program expired on January 1, 2014.

Since, in every recession, emergency benefit programs either replaced or superseded the EB program, aggregate payouts of extended benefits under EB have been relatively small. By contrast, discretionary programs have led to considerable fluctuations in aggregate benefit payments (see Figure 2).

\section{Empirical Strategy}

\section{State-level treatment variable}

I am interested in the effect of a change in benefit weeks $\Delta x_{s(c), t}$ in state $s(c)$ on economic outcomes such as employment growth, income growth, or real estate prices in county $c$. Since the effect of $\Delta x_{s(c), t}$ additional benefit weeks is likely to depend on each state's policy 
regarding weekly benefit amounts, I construct the following state-level treatment variable of de-jure benefit changes:

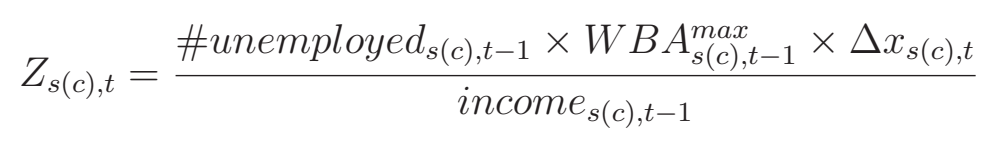

The interpretation of $Z_{s(c), t}$ is as follows: By law, each unemployed worker's benefits are capped at $W B A_{s(c), t-1}^{\max }$ dollars per week for a maximum duration of $x_{s(c), t}$ weeks. Hence, the enumerator of $Z_{s(c), t}$ computes the year-on-year change in the maximum aggregate dollar amount that unemployed households in state $s(c)$ can receive, assuming that the total unemployment numbers and maximum weekly benefit amounts $W B A_{s(c), t}^{\max }$ remain constant. $Z_{s(c), t}$ can be interpreted as the change in the state's de-jure maximum benefit-to-income ratio, caused by the change in federal benefit extensions. A state's benefit-to-income ratio can also change due to changes in unemployment or $W B A_{s(c), t}^{\max }$, but these changes are deliberately not included in $Z_{s(c), t}{ }^{12}$

Figure 3 shows how the treatment variable has varied over time and across states. Figure 4 plots the state-level treatment variable $Z_{s(c), t}$ against the actual changes in benefits for each state and year, showing that the federal UI benefit extensions can explain a large share of the variation in annual UI benefit growth. ${ }^{13}$ The slope in the relationship is less than one, owing to the fact that benefit extensions define the maximum duration, not the average duration of UI benefits in each state. The benefits of workers who find new work before reaching the end of their eligibility are not affected by benefit extensions.

\section{County-level treatment intensity}

As a starting point, I assume the following relationship between $Z_{s(c), t}$ and economic dynamics at the county level:

$$
\operatorname{semployed}_{c, t}=\alpha \times Z_{s(c), t}+\beta \times \theta_{c, t-5} \times Z_{s(c), t}+\phi_{c}+\mu_{s(c), t}+\omega_{c, t},
$$

where $Z_{s(c), t}$ enters the regression equation twice: through a linear term and through its product with county-specific factor $\theta_{c, t-5}$, implying that the treatment effect is allowed to vary across counties, along the lines of Bartik (1991). The specification controls for county fixed

\footnotetext{
${ }^{12}$ Note also that I only use changes in federal benefit extensions to measure $\Delta x_{s(c), t}$, ignoring any changes in benefit weeks induced by state government policies.

${ }^{13}$ The correlation coefficient is 69 percent, and regressing benefit growth on $Z_{s(c), t}$ yields an R-squared of 0.48 .
} 
Figure 3: Variation in the state-level treatment $Z_{s(c), t}$ over time and across states

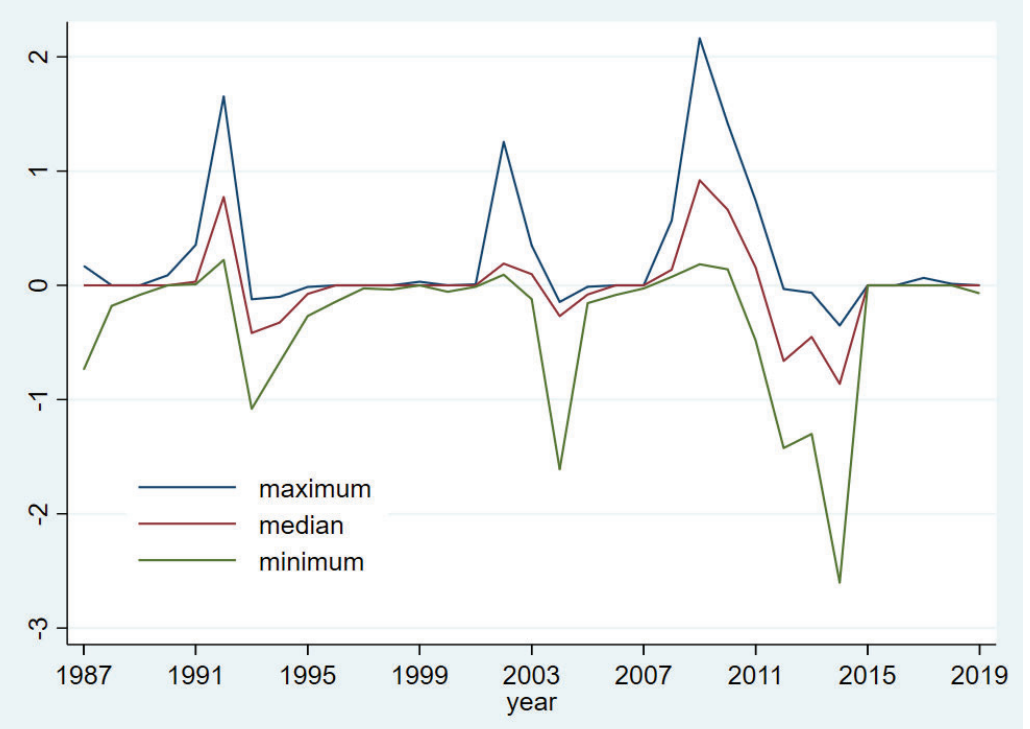

Sources: U.S. Department of Labor, Bureau of Labor Statistics, Bureau of Economic Analysis, author's calculations.

Figure 4: State-level treatment $Z_{s(c), t}$ and actual changes in state-level aggregate UI benefit transfers (in percent of lagged income)

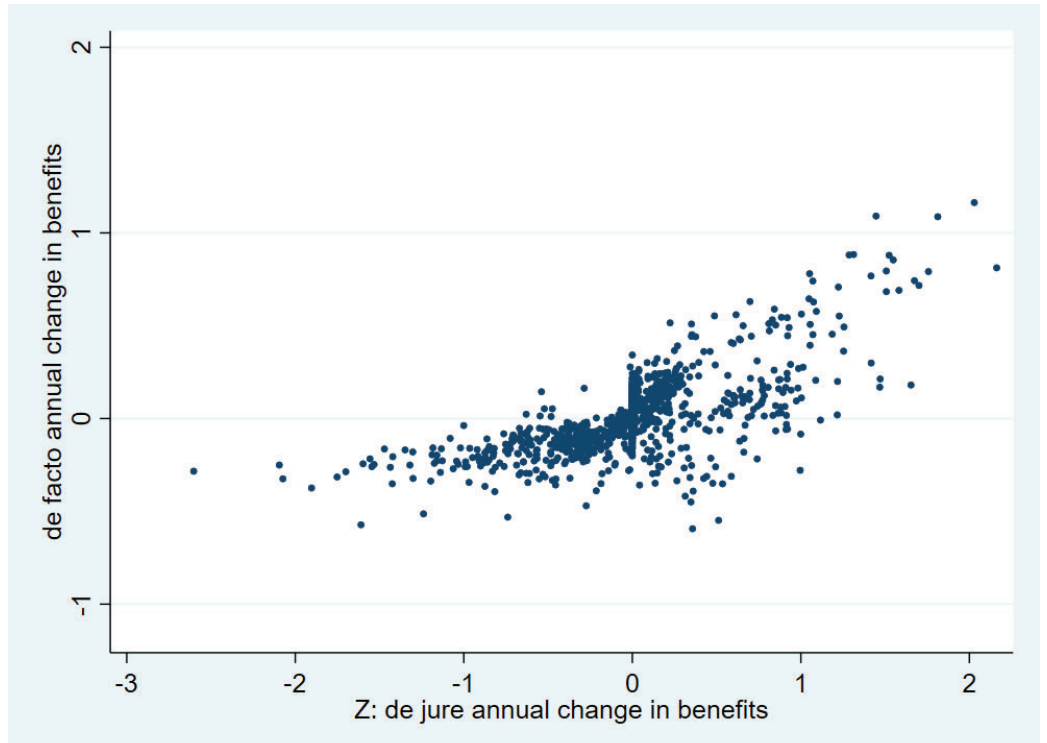

Sources: U.S. Department of Labor, Bureau of Labor Statistics, Bureau of Economic Analysis, author's calculations. 
effects $\phi_{c}$ and state-by-year fixed effects $\mu_{s(c), t}$. And $\omega_{c, t}$ is a purely exogenous disturbance. ${ }^{14}$ The term $\theta_{c, t-5}$ denotes the 15-year average of each county's UI transfer receipts (as a share of income), lagged by 5 years and normalized by the state's average UI transfer receipts:

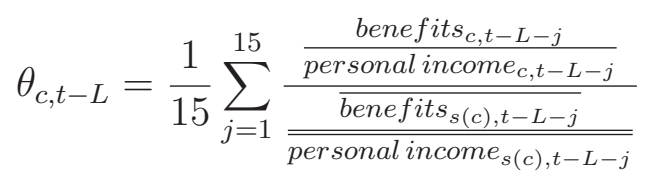

Hence, the slope coefficient $\beta$ measures the degree to which high-benefit counties are more affected by extensions than low-benefit counties. The historical differences in benefit receipts across counties reflect structural characteristics such as industry or workforce composition factors that are potentially highly persistent over time: (i) within each state, some counties face higher aggregate unemployment risk than others; (ii) the expected duration of unemployment may vary across labor markets; (iii) not all workers are eligible to receive UI benefits, and the share of eligible workers can vary across industries; (iv) weekly benefit amounts are a function of a worker's salary, and salaries vary by industry and education level.

The link between the treatment intensity $\theta_{c, t-L}$ and local unemployment can be quantified by regressing per-capita county unemployment rates on various lags of $\theta_{c, t}$ while controlling for state-by-year fixed effects. Table 1 shows that $\theta_{c, t}$ can capture a significant portion of the within-state cross-sectional variation in per-capita unemployment rates. As one would expect, the fit deteriorates with increasing lags, but the within R-squared of 0.347 in column (vi) indicates that, even at a five-year lag, $\theta_{c, t}$ can account for a third of the variation in unemployment rates.

\section{Reduced-form regressions}

Note that the coefficient $\alpha$ cannot be estimated, because $Z_{s(c), t}$ is collinear with the timevarying state fixed effects $\mu_{s(c), t}$. Omitting $\mu_{s(c), t}$ from the specification, on the other hand, would lead to a biased estimate of $\alpha$, because $Z_{s(c), t}$ is endogenous to cyclical factors at the state and national level. Instead, I rewrite the regression equation (1) as

$$
\text { semployed }_{c, t}=\beta \times \theta_{c, t-5} \times Z_{s(c), t}+\phi_{c}+\tilde{\mu}_{s(c), t}+\omega_{c, t},
$$

where $\tilde{\mu}_{s(c), t}=\alpha \times Z_{s(c), t}+\mu_{s(c), t}$. The only treatment variable in (2) is the interaction term between (i) the county-specific structural conditions $\theta_{c, t-5}$ and (ii) state-specific policy

\footnotetext{
${ }^{14}$ I allow for clustering of standard errors at the state level.
} 
changes $Z_{s(c), t}$, a term that - once the state-wide cyclical conditions that cause the policy changes at the state level are controlled for by the state-by-year fixed effects - is not affected by county-specific cyclical conditions and therefore does not suffer from endogeneity. This identification strategy is similar to Nakamura and Steinsson (2014) and Pennings (2020) but is applied at the county level. It corresponds to a DiD specification in which year-on-year differences in employment are compared for high-benefit counties and low-benefit counties. But, unlike in many well-known applications (e.g., Card and Kruger, 1994), treatment intensity $\theta_{c, t-5}$ is a continuous variable, not a binary discrete variable that splits the sample into control and treatment groups.

\section{Interpretation of treatment effects}

How important is it that we cannot estimate the value of $\alpha$ ? By definition, $\alpha$ measures the effect of on a county in which $\theta_{c, t-L}=0$. In such a county, unemployment tends to be non-existent, so that UI legislation is not relevant for the county's workers. If counties were closed economies, it would therefore be reasonable to assume that $\alpha=0$. However, U.S. counties are highly open economies, so that the usual caveats regarding estimates of cross-sectional government spending multipliers apply (see Chodorow-Reich, 2019, 2020, for detailed discussions).

First, if local changes in demand translate into higher employment at firms in far-away counties, $\alpha$ is likely greater than zero. By looking only at $\beta$, the regression framework tends to underestimate those demand effects.

The second concern is that the effect of any offsetting current or future policy changes at the national or state level are captured by the state-time fixed effect rather than the treatment

effect. For example, the effect of increases in government spending could be dampened by tighter monetary policy or by consumers' expectation of future tax increases (see Nakamura and Steinsson, 2014). In my model I cannot quantify the extent to which these macro factors reduce the treatment effects, but Chodorow-Reich (2019) finds that the difference between partial equilibrium effects and closed-economy general equilibrium multipliers is relatively small.

Finally, an important limitation of the DiD approach is that, unlike the general-equilibrium approach of McKay and Reis (2016), it does not distinguish between all the different channels through which UI benefit extensions could affect aggregate outcomes. These potential channels include labor market disincentives, housing market stabilization (Hsu et al, 2018), Keynesian demand stabilization, or demand stabilization through a reduced precautionary 
savings motive for employed persons, as in McKay and Reis (2016). ${ }^{15}$ Mian and Sufi (2014) show that we can learn about the relative importance of demand and supply-side channels by estimating (2) separately for various sectors of the economy. As they point out, tradable non-tradable sectors are more exposed to local demand shocks, while tradable sectors are more sensitive to supply-side shocks.

\section{Controls}

The main concern for my identification strategy is that of omitted variable bias, since UI benefit extensions are not the only countercyclical policy. Other transfers (such as retirement benefits or food stamps) and tax rates are correlated with benefit extensions, and their impact on county-level economic outcomes could be sensitive to factors similar to those captured by $\theta_{c, t-L}$. For example, a disproportionate share of food stamp payments is disbursed to counties with high unemployment. If omitted from equation (2), the impact of such other programs would then erroneously be attributed to $\beta$. This concern can be addressed by controlling directly for changes in benefit payments from a range of other programs, including other UI schemes (i.e., outside the state UI program), education and training assistance, retirement benefits, medical benefits, income maintenance benefits (including food stamps), veterans' benefits, and other government transfers received by households. ${ }^{16}$ Federal discretionary spending could be countercyclical as well, but its targeting to counties with low growth has not been successful (see Crucini and Vu, 2020). Nevertheless, I examine the sensitivity to federal discretionary spending by using federal civilian and military salary payments. Similar controls are considered for state and local government salaries.

For taxes, the main concern is that state governments could reduce tax rates to support activity in response to regional economic conditions, so that changes in tax rates are correlated with changes in UI benefit extensions. In most states, balanced-budget rules make such countercyclical tax policy more difficult. However, in states with progressive tax systems, the changes in average income tax rates occurs automatically. For my identification strategy, state tax policy matters if (i) effective tax rates are correlated with UI benefit extensions, and (ii) tax policy interacts with $\theta_{c, t-L}$ in a similar way as UI benefit extensions. Accordingly, I control for $\theta_{c, t-L} \times \Delta T_{s(c), t}$, where $\Delta T_{s(c), t}$ is the annual change in the state's effective

\footnotetext{
${ }^{15}$ The precautionary savings behavior of employed persons could be captured by my estimate of the treatment effect, because it depends on the interaction between perceived risk of becoming unemployed captured by past local unemployment - and the expected transfers conditional on becoming unemployed captured by the de-jure benefit generosity.

${ }^{16}$ These other transfers include dividends from the Alaska Permanent Fund and a range of transfers from ARRA programs.
} 
individual income tax rate. $^{17}$

\section{Data}

Unless indicated otherwise, economic data are from the Bureau of Labor Statistics' Regional Economic Accounts. ${ }^{18}$ Data on state income tax receipts are from the Annual Surveys on State and Local Government Finances (pre-1995) and the Quarterly Summary of State and Local Government Finances (post-1995). Sector-level employment data are from the County Business Patterns. Data on UI benefit generosity were compiled from various sources, as described in Annex A. Nominal series are deflated using the national CPI. The largest estimation sample spans from 1987 to 2019 and uses all counties. ${ }^{19}$ To be representative, all regressions weight counties by their average population over the sample. For robustness, alternative weighting methods are explored in Annex B. To reduce the influence of outliers, I winsorize $\theta_{c, t-L}$ and all control variables at their top and bottom 2.5 th percentile. ${ }^{20} \mathrm{Ob}-$ servations for which the dependent variable is in the top or bottom percentile are dropped.

\section{Reduced-form results}

\section{Employment growth}

Column (i) of Table 2 reports the baseline estimate - without any controls other than the fixed effects - for the effect of additional benefit weeks on employment growth: On average, a 1-percentage point increase in the de-jure benefit-to-income ratio leads to a 0.275 percent increase in employment. While there is some small uncertainty around this estimate, the reported standard errors indicate a high degree $(>99 \%)$ of confidence that the treatment effect $\beta$ is positive.

The remaining columns of Table 2 explore the importance of controls. First, in columns (ii), I drop the state-by-year fixed effect from the specification. Since the regressions now no longer control for the fact that benefit extensions are granted in recessions, the coefficient estimate turns negative due to reverse causality. In column (iii) I reinstate the fixed effects and control for $\theta_{c, t-L}$. The estimated treatment effect is barely affected, but the coefficient for $\theta_{c, t-L}$ is

\footnotetext{
${ }^{17}$ Effective tax rates are computed as the state's total individual income taxes divided by the state's total personal income.

${ }^{18}$ https://www.bea.gov/data/economic-accounts/regional

${ }^{19} \theta_{c, t-L}$ is constructed using data going back to 1969 . Hence, for observations in 1987 and $1988, \theta_{c, t-L}$ is constructed using only 13 and 14 years, respectively.

${ }^{20}$ Values below the 2.5 th percentile are replaced with the 2.5 th percentile value etc.
} 
highly significant and positive, indicating mean reversion of local economic dynamics. In column (iv), I add an extensive list of control variables (see Table 3 for a complete list). And column (v) controls for changes in effective state income tax rates. While tax rates are highly significant, the estimated treatment effect is robust to the additional controls.

The estimated effects are economically significant. For example, in 2014, the year after the Great-Recession-era extensions expired, the effect of a uniform 13-week benefit extension for all states would have been to increase average employment that year by more than 200,000 additional jobs nationwide. If the benefit extension levels under the EUC program from 2013 had remained in place in each state instead of expiring on January 1st, 2014, employment in 2014 would have been higher by about 560,000 jobs.

\section{Other outcomes}

Table 4 reports the effects of benefit extensions on a range of alternative outcome variables using the full set of controls. Column (ii) shows the estimated effect on labor force participation usind data from the Bureau of Labor Statistics. The point estimate is larger than the effect on employment in column (i), suggesting that, in addition to the effect of fewer workers becoming or remaining unemployed, benefit extensions set give unemployed workers an incentive to stay the labor force and search for jobs. The value of remaining in the labor force could be affected directly by the more generous benefit duration - to be eligible for benefit extensions, workers need to search for a job and hence stay in the labor force - or indirectly, because searching for a job becomes more promising when economic activity is stimulated. In principle, the increase in employment and labor force could also be due to migration, as workers from other counties may move to counties that grow faster due to the local stimulus. ${ }^{21}$ However, column (iii) shows that this effect is small and less statistically significant: labor force growth in one county does not appear to come at the expense of labor force growth in other counties.

Column (iv) tests whether more generous benefits affect the growth rate of average real wages. A positive regression coefficient would indicate that benefit extensions tend to reduce search effort or raise unemployed workers' reservation wages, thereby reducing their likelihood of finding work and employers' willingness to post vacancies, as laid out in Hagedorn et al. (2015). However, with a regression coefficient of zero, I cannot reject the hypothesis that this channel is negligible. Column (v) shows that the effects on private-sector labor earnings are significant, in line with higher employment growth. Finally, column (vi) reports the

\footnotetext{
${ }^{21}$ UI benefits are paid by the state in which a worker last worked, not by the state of residence. Hence, there is no migration of unemployed workers across state lines to benefit from more generous UI policies.
} 
estimated effect on the percentage change in residential real estate prices, using the Zillow Home Value Index from Zillow.com. The effect is positive and highly significant, in line with Hsu et al. (2018).

\section{Results by sector}

Table 5 presents the treatment effects for employment by sector using the Census Bureau's County Business Pattern data. Column (i) reports the baseline result for total county employment, with an estimated treatment effect similar to that in Table 2. In columns (ii) and (iii), the exercise is repeated for aggregate employment growth in tradable and nontradable sectors. I follow Mian and Sufi (2014) in using geographic industry concentration as a measure of tradability. For example, employment in car manufacturing, a tradable sector, is highly concentrated in a few counties, whereas car retailers, a non-tradable sector are present in almost all counties. Like Mian and Sufi (2014) I compute a Herfindahl index for each sector and group the sectors by quartile. ${ }^{22}$ Tradable industries are sectors whose Herfindahl index is in the top quartile, and non-tradable industries are those whose Herfindahl index falls into the bottom quartile.

As reported in column (ii), employment in tradable sectors does not respond to UI benefit extensions. On the one hand, from a demand perspective, this may not be surprising: a large share of the demand for car manufacturers' products comes from outside the county, so that these businesses benefit little when local consumer demand is stimulated. But, on the other hand, wage pressures, induced by local unemployed workers' reduced job search effort and higher reservation wages, would disproportionately affect manufacturers who would find it hard to pass the added wage cost on to their customers. This is because local manufacturers' pricing power may be limited by competition from firms in other counties, states, or counties, who are not exposed to the same wage cost shock. This labor market channel would imply a negative treatment effect for employment in the local manufacturing sector. The fact that the negative coefficient for manufacturing is not statistically significant adds to the evidence that supply-side effects of UI benefit extensions may be negligible.

For non-tradable sectors (column (iii)), the treatment effect is positive and statistically significant. These businesses are the ones that benefit the most from an increase in local demand. And, since non-tradable businesses such as grocery stores all operate in the same labor market as their competitors, any labor cost shock would be common to all businesses in the sector and could be passed on to consumers rather than resulting in lower employment.

\footnotetext{
${ }^{22}$ I define sectors at the 4-digit SIC/NAICS level.
} 
It is important to emphasize that the asymmetry between tradable and non-tradable sectors is, to some extent, owed to my DiD identification strategy. It is unlikely that the additional consumer demand only covers non-tradables. ${ }^{23}$ However, since car manufacturers tend to respond to national or foreign demand rather than demand in their own county, changes in car manufacturing employment that result from a nationwide increase in UI benefit extensions are filtered out by the time fixed effects.

In Table 6, I zoom into specific broader sectors of the economy. ${ }^{24}$ Construction and retail trade in columns (iii) and (vi) are the only sectors that show highly statistically significant effects. Both sectors consist, to a high degree, of non-tradable activities. Note that the positive impact of UI benefit extensions on employment in the construction sector is also consistent with the stabilizing effect on real estate prices reported in Table 4 and in Hsu et al. (2018).

\section{$5 \quad$ Fiscal multipliers}

Since benefit extensions have direct fiscal costs, it is important to compare their impact against that of alternative spending or tax measures. To translate the reduced-form results into an estimated per-dollar impact, I pursue an instrumental variables approach. The firststage regression estimates the cost of an additional benefit week in each county,

$$
\frac{\Delta \text { bene }_{\text {its }}, t}{\text { income }_{c, t-1}}=\delta \times \theta_{c, t-5} \times Z_{s(c), t}+\chi_{c}+\kappa_{s(c), t}+\epsilon_{c, t}
$$

where $\theta_{c, t-5} \times Z_{s(c), t}$ is the instrumental variable. The second stage then uses the predicted benefits to estimate the impact of additional transfers on employment growth and other outcomes:

$$
\text { semployed }_{c, t}=\gamma \times \frac{\Delta \text { benefits }_{c, t}}{\text { income }_{c, t-1}}+\psi_{c}+\eta_{s(c), t}+\zeta_{c, t}
$$

The set of fixed effects is the same as in the reduced-form regression. Hence, as was the case for the reduced form, the DiD approach in the first stage regression ensures that cross-county variations in predicted benefit growth are not driven county-specific cyclical conditions: They

\footnotetext{
${ }^{23}$ Indeed, while the services provided by grocery stores are non-tradable, most goods sold in grocery stores are tradable.

${ }^{24}$ Note that I drop all observations for which the sector of interest accounts for less than 1 percent of a county's total employment. And I drop observations in the top and bottom 5-th percentiles, since the quality of sectoral employment data is somewhat weaker than for aggregate employment data.
} 
are driven by state-wide cyclical conditions and county-specific structural factors, both of which can be controlled for.

A word of caution is in order regarding the interpretation of $\gamma$ : While the instrument is plausibly exogenous to the outcome, the actual cash benefit transfers used in (4) are most likely not the only channel through which benefit extensions affect the outcome. In addition to injecting cash into the local economy, UI programs have a crucial role in reducing idiosyncratic household income risk, which gives rise to several powerful channels through which benefits affect aggregate demand. Hsu et al. (2018) stress the importance of UI benefits in preventing mortgage defaults and the positive effect on real estate prices - as confirmed in my analysis. By stabilizing the housing market, they help preserve net worth of all households and facilitate the use of housing wealth to smooth consumption. McKay and Reis (2016) highlight that the anticipation of insurance through UI programs reduces the need for precautionary savings in times of high economic uncertainty. Therefore, the aggregate consumption response from a more generous benefit scheme can be substantially larger than the impact of the actual cash transfers alone, as employed households spend more freely in response to the reduced future consumption risk. Such effects are captured by $\gamma$ even though they are unrelated to the cash payments. However, my objective is first and foremost to determine the overall per-dollar impact of the benefit extension policy, not the narrow impact of the actual benefit transfers alone so that the specification in (3) and (4) remains appropriate and useful.

The results are presented in Table 7. Column (i) reports the first-stage regression results estimating the impact of a change in de-jure maximum benefit generosity $Z_{s(c), t}$ on the yearon-year change in actual benefit spending - i.e., the relationship depicted in Figure 4. As expected, the first-stage coefficient is positive but smaller than unity. A one-dollar increase in maximum benefits is associated with an increase in actual benefits of less than 5 cents. The coefficient is smaller than 1 because not all unemployed workers receive the maximum weekly benefit amount and because some of them find a job before reaching the end of their state's maximum benefit duration. The F-statistic of 158.3 indicates that the link between benefit extensions and transfer payments is highly significant. The second-stage results are reported in columns (ii) and (iii), for employment growth and labor earnings growth, respectively. Increasing benefits by one percent point of total household income leads to 2.451 percent more employment. And for every dollar paid in additional UI benefits, private sector labor earnings increase by 1.925 dollars.

Columns (v) and (vi) report the results from an OLS approach, highlighting the strong negative relationship between benefit payments and economic activity, even when applying the 
differences-in-differences approach: since benefit payments respond to local economic shocks, it is crucial to apply the instrumentation to use only the variation in benefits generated by the federal policy changes that are exogenous to county-specific developments.

The estimated multiplier in column (iv) is almost exactly the same as in Di Maggio and Kermani (2016) and broadly in line with previous estimates in the literature on cross-sectional government spending multipliers. Suarez-Serrato and Wingender (2016) estimate an effect of federal government spending on county-level aggregate personal incomes of between 1.7 and 2, and Shoag (2016) finds an effect of state government spending on in-state income of 2.1. Reviewing the literature on output multipliers, Chodorow-Reich (2019) settles on an estimate of around 1.8.

Still, it may be surprising to see such large fiscal multipliers. But it is important to keep in mind that UI benefit extensions can affect activity through several channels: a Keynesian demand effect from additional cash inflows, the reduced need for precautionary savings of employed workers, and a wealth effect due to housing market stabilization (Hsu et al., 2018). Ganong and Noel (2019) find that unemployed households have a higher marginal propensity to consume (MPC), and Kekre (2016) shows that, under plausible assumptions, any Keynesian demand effect from UI benefit extensions is amplified due to the heterogeneity in MPC. Finally, it is worth pointing to Auerbach and Gorodnichenko (2012) who provide evidence that fiscal multipliers tend to be larger in economies operating below capacity. And additional government spending from UI benefit extensions is, by design, targeted to flow to regions with high unemployment. ${ }^{25}$

\section{Conclusion}

This paper has provided strong evidence that, over the past three decades, temporary extensions of UI benefit duration have, on average, helped stimulate economic activity. Local fiscal multipliers for UI benefits are as large as those for other types of government spending. It is worth reiterating that these effects are underestimated by my methodology, because demand effects in tradable sectors are filtered out by the state-by-year fixed effects.

The paper finds no negative effect on tradable sectors that are, in theory, more sensitive to labor market disincentives than non-tradable sectors. Neither is there evidence that benefit extensions affect average wages. Hence, labor market disincentive effects and search

\footnotetext{
${ }^{25}$ By contrast, when looking at spending under the American Recovery and Reinvestment Act, Crucini and $\mathrm{Vu}(2020)$ find large room for improvement in the targeting of discretionary spending.
} 
externalities appear to be negligible relative to the positive employment effects coming from stimulated aggregate demand.

The estimated size of the multipliers makes UI benefit extensions an attractive alternative to other, less targeted, stabilization policies. However, the discretionary nature of UI extension programs in recessions leads to policy uncertainty and implementation lags. Until 1981 the EB program had an additional national trigger, so that extensions were granted automatically based on both state and national unemployment rates (Lake, 2002). Reforming the EB program to automate benefit extensions in recessions, by reintroducing a national trigger, would eliminate the policy uncertainty and thereby further enhance the capacity of UI benefit extensions to act as automatic stabilizers. 


\section{References}

[1] Auerbach, A.J. and Gorodnichenko, Y., 2012. Measuring the output responses to fiscal policy. American Economic Journal: Economic Policy, 4(2), pp.1-27.

[2] Bartik, T.J., 1991. Who benefits from state and local economic development policies?.

[3] Bayer, C., Born, B., Luetticke, R. and Müller, G.J., 2020. The Coronavirus Stimulus Package: How large is the transfer multiplier?.

[4] Card, D., Chetty, R. and Weber, A., 2007. Cash-on-hand and competing models of intertemporal behavior: New evidence from the labor market. The Quarterly journal of economics, 122(4), pp.1511-1560.

[5] Card, D. and Krueger, A.B., 1994. Minimum wages and employment: A case study of the fast-food industry in New Jersey and Pennsylvania. The American Economic Review, 84(4), p.772.

[6] Card, D. and Levine, P.B., 2000. Extended benefits and the duration of UI spells: evidence from the New Jersey extended benefit program. Journal of Public economics, 78(12), pp.107-138.

[7] Chetty, R., 2008. Moral hazard versus liquidity and optimal unemployment insurance. Journal of political Economy, 116(2), pp.173-234.

[8] Chodorow-Reich, G., 2019. Geographic cross-sectional fiscal spending multipliers: What have we learned?. American Economic Journal: Economic Policy, 11(2), pp.1-34.

[9] Chodorow-Reich, G., 2020. Regional data in macroeconomics: some advice for practitioners. Journal of Economic Dynamics and Control 115.

[10] Chodorow-Reich, G. and Coglianese, J.M., 2019. Unemployment Insurance and Macroeconomic Stabilization. Unemployment Insurance and Macroeconomic Stabilization." In Recession Ready, ed. Heather Boushey, Ryan Nunn, and Jay Shambaugh.

[11] Chodorow-Reich, G. and Karabarbounis, L., 2016. The limited macroeconomic effects of unemployment benefit extensions (No. w22163). National Bureau of Economic Research.

[12] Crucini, M.J. and Vu, N.T., 2020. Did the American Recovery and Reinvestment Act help counties most affected by the Great Recession. Review of Economic Dynamics. 
[13] Di Maggio, M. and Kermani, A., 2016. The importance of unemployment insurance as an automatic stabilizer (No. w22625). National Bureau of Economic Research.

[14] Dupor, B., Karabarbounis, M., Kudlyak, M. and Mehkari, M.S., 2019. Regional Consumption Responses and the Aggregate Fiscal Multiplier.

[15] Faria-e-Castro, M., 2020. Fiscal policy during a pandemic. FRB St. Louis Working Paper, (2020-006).

[16] Ganong, P. and Noel, P., 2019. Consumer spending during unemployment: Positive and normative implications. American Economic Review, 109(7), pp.2383-2424

[17] Giambattista, E. and Pennings, S., 2017. When is the government transfer multiplier large?. European Economic Review, 100, pp.525-543.

[18] Hagedorn, M., Karahan, F., Manovskii, I. and Mitman, K., 2013. Unemployment benefits and unemployment in the great recession: the role of macro effects (No. w19499). National Bureau of Economic Research.

[19] Hagedorn, M., Manovskii, I. and Mitman, K., 2015. The Impact of Unemployment Benefit Extensions on Employment: The 2014 Employment Miracle? (No. w20884). National Bureau of Economic Research.

[20] Hsu, J.W., Matsa, D.A. and Melzer, B.T., 2018. Unemployment insurance as a housing market stabilizer. American Economic Review, 108(1), pp.49-81.

[21] Jaeger, S., Schoefer, B., Young, S. and Zweimueller, J., 2020. Wages and the Value of Nonemployment. The Quarterly Journal of Economics, 135(4), pp.1905-1963.

[22] Kekre, R., 2016. Unemployment Insurance in Macroeconomic Stabilization.

[23] Kroft, K. and Notowidigdo, M.J., 2016. Should unemployment insurance vary with the unemployment rate? Theory and evidence. The Review of Economic Studies, 83(3), pp.1092-1124.

[24] Krueger, A.B. and Mueller, A., 2010. Job search and unemployment insurance: New evidence from time use data. Journal of Public Economics, 94(3-4), pp.298-307.

[25] Krueger, A.B. and Mueller, A.I., 2016. A contribution to the empirics of reservation wages. American Economic Journal: Economic Policy, 8(1), pp.142-79.

[26] Lake, J., 2002. Temporary Programs to Extend Unemployment Compensation (RL31277). Washington, DC: Congressional Research Service. 
[27] Lake, J., 2003. Unemployment Benefits: Temporary Extended Unemployment Compensation (TEUC) Program (RS21397). Washington, DC: Congressional Research Service.

[28] Lalive, R., Van Ours, J. and Zweimüller, J., 2006. How changes in financial incentives affect the duration of unemployment. The Review of Economic Studies, 73(4), pp.10091038.

[29] Lalive, R. and Zweimüller, J., 2004. Benefit entitlement and unemployment duration: The role of policy endogeneity. Journal of public economics, 88(12), pp.2587-2616.

[30] Landais, C., Michaillat, P. and Saez, E., 2018. A macroeconomic approach to optimal unemployment insurance: Theory. American Economic Journal: Economic Policy, 10(2), pp.152-81.

[31] Landais, C., Michaillat, P. and Saez, E., 2018. A macroeconomic approach to optimal unemployment insurance: Applications. American Economic Journal: Economic Policy, 10(2), pp.182-216.

[32] Marinescu, I., 2017. The general equilibrium impacts of unemployment insurance: Evidence from a large online job board. Journal of Public Economics, 150, pp.14-29.

[33] McKay, A. and Reis, R., 2016. The role of automatic stabilizers in the US business cycle. Econometrica, 84(1), pp.141-194.

[34] Mian, A. and Sufi, A., 2014. What explains the 2007-2009 drop in employment?. Econometrica, 82(6), pp.2197-2223.

[35] Nakamura, E. and Steinsson, J., 2014. Fiscal stimulus in a monetary union: Evidence from US regions. American Economic Review, 104(3), pp.753-92.

[36] N.Y. State Department of Labor, 2014. A history of UI legislation in the United States and NYS 1935-2014. Division of Research and Statistics

[37] Oh, H. and Reis, R., 2012. Targeted transfers and the fiscal response to the great recession. Journal of Monetary Economics, 59, pp.S50-S64.

[38] Pennings, S., 2020. Cross-region transfers in a monetary union. Policy Research Working Paper 9244, World Bank.

[39] Schmieder, J.F., Von Wachter, T. and Bender, S., 2012. The effects of extended unemployment insurance over the business cycle: Evidence from regression discontinuity estimates over 20 years. The Quarterly Journal of Economics, 127(2), pp.701-752. 
[40] Shoag, Daniel. 2016. The Impact of Government Spending Shocks: Evidence on the Multiplier from State Pension Plan Returns.

[41] Suarez Serrato, J.C. and Wingender, P., 2016. Estimating local fiscal multipliers. National Bureau of Economic Research.

[42] U.S. Department of Labor, 2002. Unemployment Insurance Program Letter No. 17-02. https://oui.doleta.gov/dmstree/uipl/uipl2k2/uipl_1702a.pdf

[43] U.S. Department of Labor, 2018. Chronology of federal unemployment compensation laws, https://oui.doleta.gov/unemploy/pdf/chronfedlaws.pdf 
Table 1: Cross-sectional link between local unemployment and $\theta_{c, t}$ at various lags

\begin{tabular}{|c|c|c|c|c|c|c|}
\hline & \multicolumn{6}{|c|}{ per-capita county unemployment rate } \\
\hline & year $\mathrm{t}$ & year $t+1$ & year $\mathrm{t}+2$ & year $\mathrm{t}+3$ & year $\mathrm{t}+4$ & year $\mathrm{t}+5$ \\
\hline & (i) & (ii) & (iii) & (iv) & $(\mathrm{v})$ & (vi) \\
\hline$\theta_{c, t}$ & $\begin{array}{c}1.091^{* * *} \\
(0.063)\end{array}$ & $\begin{array}{c}1.058^{* * *} \\
(0.061)\end{array}$ & $\begin{array}{c}1.030^{* * *} \\
(0.059)\end{array}$ & $\begin{array}{c}1.004^{* * *} \\
(0.057)\end{array}$ & $\begin{array}{c}0.980^{* * *} \\
(0.055)\end{array}$ & $\begin{array}{c}0.957^{* * *} \\
(0.053)\end{array}$ \\
\hline State-by-year FE & yes & yes & yes & yes & yes & yes \\
\hline $\mathrm{N}$ & 90169 & 90169 & 90169 & 90169 & 90169 & 90169 \\
\hline within R-squared & 0.414 & 0.395 & 0.381 & 0.369 & 0.358 & 0.347 \\
\hline
\end{tabular}

Notes: standard errors, corrected for clustering by state, in parentheses; significance levels: $*, * *, * * *=10 \%, 5 \%$, and $1 \%$. Observations weighted by average county population.

Table 2: Reduced-form results: employment growth

\begin{tabular}{|c|c|c|c|c|c|}
\hline & \multicolumn{5}{|c|}{ dependent variable: $\Delta$ employment $^{1}$} \\
\hline & (i) & (ii) & (iii) & (iv) & $(\mathrm{v})$ \\
\hline$\theta_{c, t-5} \times Z_{s(c), t}$ & $\begin{array}{c}0.275^{* * * *} \\
(0.049)\end{array}$ & $\begin{array}{c}-0.721^{* * *} \\
(0.055)\end{array}$ & $\begin{array}{c}0.265^{* * * *} \\
(0.049)\end{array}$ & $\begin{array}{c}0.304^{* * *} \\
(0.047)\end{array}$ & $\begin{array}{c}0.269^{* * *} \\
(0.048)\end{array}$ \\
\hline$\theta_{c, t-5}$ & & & $\begin{array}{c}0.611^{* * *} \\
(0.075)\end{array}$ & $\begin{array}{c}0.382^{* * *} \\
(0.073)\end{array}$ & $\begin{array}{c}0.390 * * * \\
(0.073)\end{array}$ \\
\hline$\theta_{c, t-5} \times \Delta T_{s(c), t}$ & & & & & $\begin{array}{c}-0.363^{* * * *} \\
(0.094)\end{array}$ \\
\hline County FE & yes & yes & yes & yes & yes \\
\hline State-by-year FE & yes & no & yes & yes & yes \\
\hline Additional controls (see Table 3 ) & no & no & no & yes & yes \\
\hline $\mathrm{N}$ & 100,552 & 100,585 & 100,552 & 100,533 & 100,533 \\
\hline
\end{tabular}


Table 3: List of control variables

\begin{tabular}{|c|c|c|c|}
\hline Series & Notes & Time series structure & Sources $* *$ \\
\hline $\begin{array}{l}\text { Macroeconomic conditions and demographics: } \\
\text { farm proprietor earnings } \\
\log (\text { population }) \\
\log (\text { personal income per capita) } \\
\text { dividend, interest, and rental income }\end{array}$ & $*$ & $\begin{array}{l}\text { year t-1 level and change, year t- } 2 \text { change } \\
\text { year t-1 level and change, year t- } 2 \text { change } \\
\text { year t-1 level and change, year t- } 2 \text { change } \\
\text { year t-1 level and change, year t- } 2 \text { change }\end{array}$ & $\begin{array}{l}\text { I71 } \\
\text { I20 } \\
\text { I10 } \\
\text { I46 }\end{array}$ \\
\hline $\begin{array}{l}\text { Government salaries and wages: } \\
\text { state and local government wages and salaries } \\
\text { federal government wages and salaries } \\
\text { military wages and salaries }\end{array}$ & $\begin{array}{l}* \\
* \\
*\end{array}$ & $\begin{array}{l}\text { year } t \text { change, year } t-1 \text { level and change } \\
\text { year } t \text { change, year t- } 1 \text { level and change } \\
\text { year t change, year t- } 1 \text { level and change }\end{array}$ & $\begin{array}{l}\text { S } 930 / N 2010 \\
\text { S910N2001 } \\
\text { S920/N2002 }\end{array}$ \\
\hline $\begin{array}{l}\text { Government transfers: } \\
\text { other UI benefits (e.g., ex-military, ex-federal govt workers) } \\
\text { retirement benefits } \\
\text { income maintenance benefits } \\
\text { medical benefits } \\
\text { veteran benefits } \\
\text { education and training assistance } \\
\text { refundable tax credits } \\
\text { other current transfers }\end{array}$ & $\begin{array}{l}* \\
* \\
* \\
* \\
* \\
* \\
* \\
*\end{array}$ & $\begin{array}{l}\text { year t change, year t-1 level } \\
\text { year t change, year t-1 level } \\
\text { year t change, year t-1 level } \\
\text { year t change, year t- } 1 \text { level } \\
\text { year t change, year t- } 1 \text { level } \\
\text { year t change, year t- } 1 \text { level } \\
\text { year t change, year t- } 1 \text { level } \\
\text { year t change, year t- } 1 \text { level }\end{array}$ & $\begin{array}{l}\mathrm{T} 2420 \\
\mathrm{~T} 2100 \\
\mathrm{~T} 2300 \\
\mathrm{~T} 2200 \\
\mathrm{~T} 2500 \\
\mathrm{~T} 2600 \\
\mathrm{~T} 5000 \\
\mathrm{~T} 2700\end{array}$ \\
\hline $\begin{array}{l}\text { Contribution rates: } \\
\text { effective employer contribution rate to social insurance and pen- } \\
\text { sion and insurance funds } \\
\text { effective employee contribution rate to social insurance }\end{array}$ & & $\begin{array}{l}\text { year t-1 level, year t-2 level } \\
\text { year t-1 level, year t-2 level }\end{array}$ & $\begin{array}{l}\mathrm{I} 60 \\
\mathrm{I} 37\end{array}$ \\
\hline
\end{tabular}
Notes:

* Series marked with * are scaled by lagged personal income when the dependent variable is change in earnings. For all other dependent variables, they are scaled by lagged population.

** Codes refer to series codes in the BEAs Regional Economic Accounts. $\mathrm{I}=$ Income, $\mathrm{T}=$ current transfer, $\mathrm{S} / \mathrm{N}=\mathrm{SIC} / \mathrm{NAICS}$ industry-level data. 
Table 4: Reduced-form results across outcome variables

\begin{tabular}{|c|c|c|c|c|c|c|}
\hline & \multicolumn{6}{|c|}{ dependent variable: ${ }^{1}$} \\
\hline & \multicolumn{2}{|c|}{$\Delta$ employment $\stackrel{\Delta \text { labor }}{\text { force }}$} & \multicolumn{2}{|c|}{$\Delta$ population $\Delta$ wages } & \multirow{2}{*}{$\begin{array}{c}\Delta \text { earnings } \\
(\mathrm{v})\end{array}$} & \multirow{2}{*}{$\begin{array}{c}\Delta \text { home } \\
\text { values } \\
\text { (vi) }\end{array}$} \\
\hline & (i) & (ii) & (iii) & (iv) & & \\
\hline$\theta_{c, t-5} \times Z_{s(c), t}$ & $\begin{array}{c}0.269^{* * *} \\
(0.048)\end{array}$ & $\begin{array}{c}0.439 * * * \\
(0.057)\end{array}$ & $\begin{array}{l}0.027^{*} \\
(0.015)\end{array}$ & $\begin{array}{c}0.009 \\
(0.045)\end{array}$ & $\begin{array}{c}0.166^{* * *} \\
(0.039)\end{array}$ & $\begin{array}{c}0.222^{* *} \\
(0.085)\end{array}$ \\
\hline$\theta_{c, t-5}$ & $\begin{array}{c}0.390^{* * *} \\
(0.073)\end{array}$ & $\begin{array}{c}0.288^{* * *} \\
(0.066)\end{array}$ & $\begin{array}{c}0.100^{* *} \\
(0.038)\end{array}$ & $\begin{array}{c}0.149^{* * *} \\
(0.054)\end{array}$ & $\begin{array}{c}0.303^{* * *} \\
(0.070)\end{array}$ & $\begin{array}{c}0.918^{* * *} \\
(0.210)\end{array}$ \\
\hline$\theta_{c, t-5} \times \Delta T_{s(c), t}$ & $\begin{array}{c}-0.363^{* * *} \\
(0.094)\end{array}$ & $\begin{array}{c}-0.468^{* * *} \\
(0.151)\end{array}$ & $\begin{array}{c}0.085^{* *} \\
(0.042)\end{array}$ & $\begin{array}{c}-0.165^{*} \\
(0.095)\end{array}$ & $\begin{array}{c}-0.213^{*} \\
(0.109)\end{array}$ & $\begin{array}{c}0.212 \\
(0.236)\end{array}$ \\
\hline County FE & yes & yes & yes & yes & yes & yes \\
\hline State-by-year FE & yes & yes & yes & yes & yes & yes \\
\hline Additional controls (see Table 3 ) & yes & yes & yes & yes & yes & yes \\
\hline $\mathrm{N}$ & 100,533 & 85,297 & 100,530 & 100,530 & 100,532 & 41,813 \\
\hline Coverage & $\begin{array}{l}1987- \\
2019\end{array}$ & $\begin{array}{l}1991- \\
2019\end{array}$ & $\begin{array}{l}1987- \\
2019\end{array}$ & $\begin{array}{l}1987- \\
2019\end{array}$ & $\begin{array}{l}1987- \\
2019\end{array}$ & $\begin{array}{l}1997- \\
2019\end{array}$ \\
\hline
\end{tabular}

Notes: standard errors, corrected for clustering by state, in parentheses; significance levels:

$*, * *, * * *=10 \%, 5 \%$, and $1 \%$. Observations weighted by average county population.

${ }^{1} \Delta$ employment in percent

Table 5: Results for tradable and non-tradable sectors

\begin{tabular}{|c|c|c|c|}
\hline & \multicolumn{3}{|c|}{ dependent variable: $\Delta$ employment } \\
\hline & $\begin{array}{c}\text { all } \\
\text { sectors }\end{array}$ & tradable & $\begin{array}{c}\text { non- } \\
\text { tradable }\end{array}$ \\
\hline & (i) & (ii) & (iii) \\
\hline$\theta_{c, t-5} \times Z_{s(c), t}$ & $\begin{array}{c}0.325^{* * *} \\
(0.081)\end{array}$ & $\begin{array}{c}0.109 \\
(0.452)\end{array}$ & $\begin{array}{c}0.277^{* *} \\
(0.104)\end{array}$ \\
\hline$\theta_{c, t-5}$ & $\begin{array}{c}0.343^{* * *} \\
(0.127)\end{array}$ & $\begin{array}{c}0.685 \\
(0.481)\end{array}$ & $\begin{array}{c}0.146 \\
(0.106)\end{array}$ \\
\hline$\theta_{c, t-5} \times \Delta T_{s(c), t}$ & $\begin{array}{l}-0.244 \\
(0.285)\end{array}$ & $\begin{array}{c}-2.419^{* *} \\
(1.043)\end{array}$ & $\begin{array}{l}-0.027 \\
(0.264)\end{array}$ \\
\hline County FE & yes & yes & yes \\
\hline State-by-year FE & yes & yes & yes \\
\hline Additional controls (see Table 3 ) & yes & yes & yes \\
\hline $\mathrm{N}$ & 90,747 & 86,365 & 88,193 \\
\hline
\end{tabular}

Notes: standard errors, corrected for clustering by state, in parentheses; significance levels: $*, * *, * * *=10 \%, 5 \%$, and 1\%. Sample: 1987-2017; observations weighted by average county population.

${ }^{1} \Delta$ employment in percent 
Table 6: Results by sector

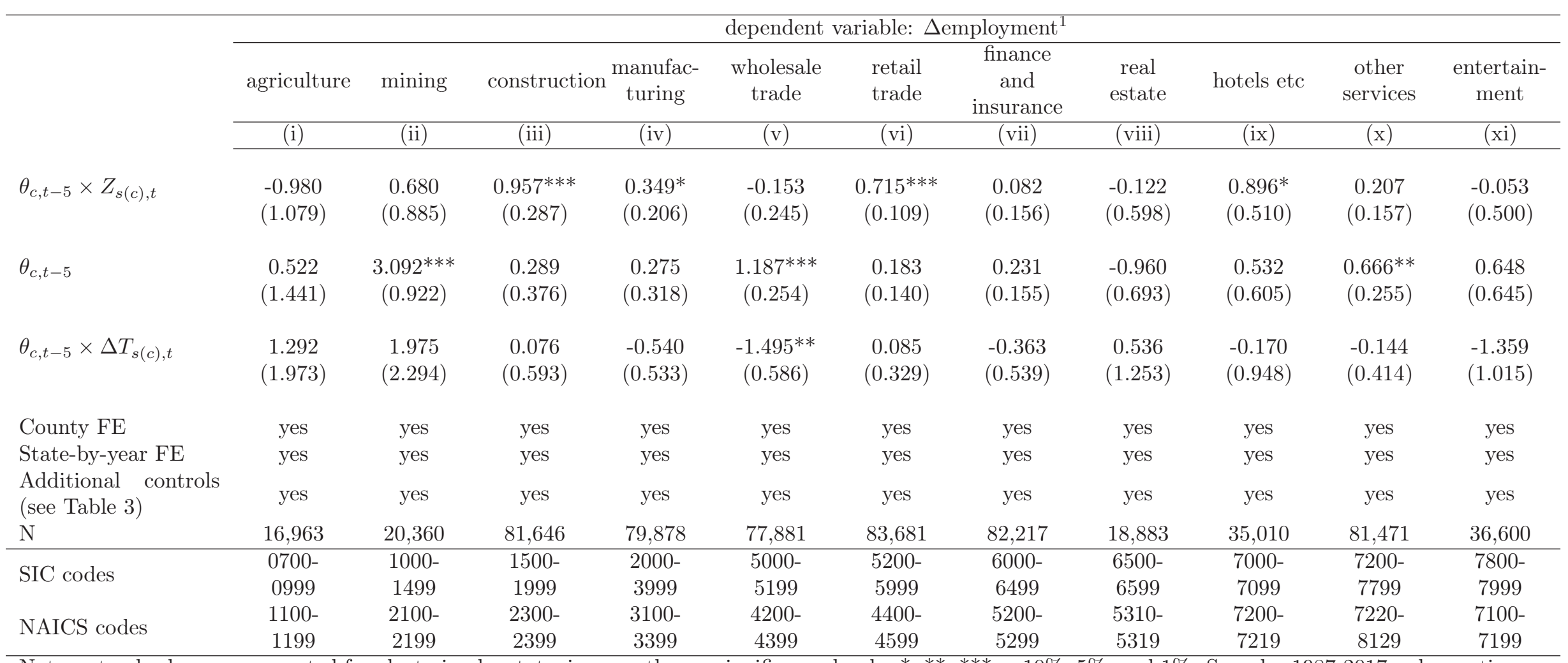

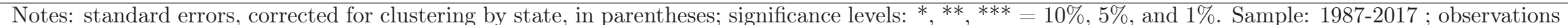

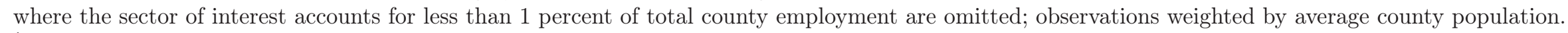

${ }^{1} \Delta$ employment in percent 
Table 7: Fiscal multipliers

\begin{tabular}{|c|c|c|c|c|c|}
\hline \multirow[t]{4}{*}{$x^{2}$} & \multicolumn{5}{|c|}{ dependent variable: $^{1}$} \\
\hline & $\frac{\Delta \text { benefits }_{c, t}}{\text { income }_{c, t-1}}$ & $\Delta$ employment & $\Delta$ earnings & $\Delta$ employment & $\Delta$ earnings \\
\hline & $\begin{array}{c}\text { OLS } \\
\text { (first } \\
\text { stage) }\end{array}$ & $\begin{array}{c}\text { IV } \\
\text { (second } \\
\text { stage) }\end{array}$ & $\begin{array}{c}\text { IV } \\
\text { (second } \\
\text { stage) }\end{array}$ & OLS & OLS \\
\hline & (i) & (ii) & (iii) & (iv) & $(\mathrm{v})$ \\
\hline$\frac{\Delta \text { benefits }_{c, t}}{\text { income }_{c, t-1}}$ & & $\begin{array}{c}2.451^{* * *} \\
(0.656)\end{array}$ & $\begin{array}{c}1.925^{* * *} \\
(0.494)\end{array}$ & $\begin{array}{c}-2.339^{* * *} \\
(0.186)\end{array}$ & $\begin{array}{c}-2.069^{* * *} \\
(0.155)\end{array}$ \\
\hline$\theta_{c, t-5} \times Z_{s(c), t}$ & $\begin{array}{c}0.047^{* * *} \\
(0.004)\end{array}$ & & & & \\
\hline$\theta_{c, t-5}$ & $\begin{array}{c}-0.008^{* * *} \\
(0.002)\end{array}$ & $\begin{array}{c}0.411^{* * *} \\
(0.075)\end{array}$ & $\begin{array}{c}0.323^{* * *} \\
(0.071)\end{array}$ & $\begin{array}{c}0.380^{* * *} \\
(0.074)\end{array}$ & $\begin{array}{c}0.293^{* * *} \\
(0.071)\end{array}$ \\
\hline$\theta_{c, t-5} \times \Delta T_{s(c), t}$ & $\begin{array}{l}-0.009 \\
(0.008)\end{array}$ & $\begin{array}{c}-0.290^{* * *} \\
(0.085)\end{array}$ & $\begin{array}{l}-0.154 \\
(0.094)\end{array}$ & $\begin{array}{c}-0.623^{* * *} \\
(0.115)\end{array}$ & $\begin{array}{c}-0.434^{* * *} \\
(0.135)\end{array}$ \\
\hline County FE & yes & yes & yes & yes & yes yes \\
\hline State-by-year FE & yes & yes & yes & yes & yes yes \\
\hline Additional controls (see Table 3 ) & yes & yes & yes & yes & yes yes \\
\hline $\mathrm{N}$ & 100,524 & 100,533 & 100,532 & 100,533 & 100,532 \\
\hline First-stage F statistic & 158.3 & & & & \\
\hline
\end{tabular}




\section{Annex}

\section{A Data on UI benefit generosity}

\section{Benefit extensions}

For each state, the length of benefit extensions in a calendar year is computed as the average number of maximum benefit extension weeks over all weeks of that year. In a given week, the maximum benefit extension is computed as the sum of the following:

1. Extended benefits: Since 2003, weekly reports by the Department of Labor indicate whether a state was eligible and participated in the EB program, as well as the number of weeks added (13 or 20). ${ }^{26}$ For pre-2003 years, I use the Department of Labor's Weekly Claims and Extended Benefits Trigger Data. ${ }^{27}$ The difference between the two sources is that the second source does not contain information on the duration of benefit extensions. For each week reported as having the EB trigger turned on before 2003, I therefore assume only 13 additional benefit weeks, hence assuming no opt-in for a 20-week extension in times of a higher state unemployment rate.

2. EUC, 1991-94: I rely on information on how additional benefit weeks for each state evolved under the 1991-94 emergency unemployment compensation legislation compiled by Lake (2002). During the time the EUC is in effect, I impose that all EB triggers are turned off.

3. TEUC, 2002-04: I follow the description in Lake (2003) according to which the benefit duration under the first-tier is the minimum of half the regular UI benefit duration and 13 weeks. Benefit duration under the second tier (TEUC-X) is the same as under the first tier but is only available for states in which the trigger is on. The trigger is determined as follows:

"A state is classified as a high-unemployment state if the state's insured unemployment rate (IUR) is at least $4 \%$, and at least $120 \%$ of the average of the 13-week IUR in the prior 2 years for the same 13 -week calendar period. ... Once a state has triggered on to TEUC-X, that state remains classified as high unemployment for 13 weeks, regardless of whether or not the state's IUR drops below the $4 \%$ criterion during that 13 -week period. At the end

\footnotetext{
${ }^{26}$ see https://oui.doleta.gov/unemploy/claims_arch.asp

${ }^{27}$ See https://oui.doleta.gov/unemploy/csv/ar539.csv
} 
of that 13 weeks, the state will trigger off TEUC-X if that state's IUR has fallen below $4 \%$. If the state's IUR remains above $4 \%$ and continues to meet the $120 \%$ criterion, the state will continue to be classified as a highunemployment state for an additional 13 weeks. This classification process proceeds in 13-week increments for the life of the TEUC program" - Lake (2003)

After computing the state IUR from the Department of Labor's Weekly Claims and Extended Benefits Trigger Data, I apply this rule for each state to determine eligibility for second-tier benefits.

4. EUC, 2008-13: To determine each state's eligibility for extensions under Tier 2, Tier 3, and Tier 4, I rely on the weekly reports by the U.S. Department of Labor. ${ }^{28}$ Information on changes in the maximum numbers of benefit weeks under each tier is from U.S. Department of Labor (2018) and the laws referenced therein.

\section{Maximum weekly benefit amounts}

Information on maximum weekly benefit amounts is compiled semi-annually, in January and July, by the U.S. Department of Labor. ${ }^{29}$ I parse each report using an R script and make some manual corrections, mainly for reports in the 1980s and 1990s, reflecting the lower quality of scanned pdfs from that era. Whenever the maximum benefit amount indicates a range (reflecting, for example, the number of dependents), I take the average of the upper and lower bound). I then average the January and July numbers to arrive at an annual number.

\footnotetext{
${ }^{28}$ see https://oui.doleta.gov/unemploy/claims_arch.asp

${ }^{29}$ See https://oui.doleta.gov/unemploy/content/sigpros/2020-2029/January2020.pdf for an example.
} 


\section{B Additional results}

Table 8: Alternative weighting methods

\begin{tabular}{|c|c|c|c|}
\hline & \multicolumn{3}{|c|}{ dependent variable: $\Delta$ employment $^{1}$} \\
\hline & (i) & (ii) & (iii) \\
\hline$\theta_{c, t-5} \times Z_{s(c), t}$ & $\begin{array}{c}0.269^{* * *} \\
(0.048)\end{array}$ & $\begin{array}{c}0.278^{* * *} \\
(0.043)\end{array}$ & $\begin{array}{c}0.294^{* * *} \\
(0.056)\end{array}$ \\
\hline$\theta_{c, t-5}$ & $\begin{array}{c}0.390^{* * *} \\
(0.073)\end{array}$ & $\begin{array}{c}0.419^{* * *} \\
(0.061)\end{array}$ & $\begin{array}{c}0.406^{* * *} \\
(0.070)\end{array}$ \\
\hline$\theta_{c, t-5} \times \Delta T_{s(c), t}$ & $\begin{array}{c}-0.363^{* * *} \\
(0.094)\end{array}$ & $\begin{array}{c}-0.295^{* * *} \\
(0.086)\end{array}$ & $\begin{array}{c}-0.226^{* *} \\
(0.090)\end{array}$ \\
\hline Weighting method & $\begin{array}{l}\text { by popu- } \\
\text { lation }\end{array}$ & equal & by $\sqrt{a r e a}$ \\
\hline County FE & yes & yes & yes \\
\hline State-by-year FE & yes & yes & yes \\
\hline Additional controls (see Table 3) & yes & yes & yes \\
\hline $\mathrm{N}$ & 100,533 & 100,533 & 99,630 \\
\hline
\end{tabular}

